\title{
PERANAN ETIKA PROFESI DALAM PERILAKU AKUNTAN
}

\section{ABSTRACT}

The aim of the research is to present the development of behavioral accounting research related to the ethical individuals who manage information. The research is literature review from the results of of the research done by other researchers. The research result showed each individual in the execution of professional duties should consider the ethics of professions such as in the use of authority ownership, establish connections with politicians, character building manager, and in the preparation of the company's budget. Professional ethics is very important to be applied in order to support the implementation of behavioral accounting that may affect the smooth operation of the company both on the policy side or the other.

\section{Key Words : Accounting Behavioral, Professional ethics, Possession, Character manager, Corporate budget.}

\section{PENDAHULUAN}

Riset akuntansi keperilakuan yang dilakukan berkaitan dengan perilaku individu dalam mengelola informasi baik untuk tujuan keuangan maupun kebijakan. Akuntansi keperilakuan merupakan bidang yang sangat luas. Dalam perkembangannya diawali dari bidang akuntansi manajemen dan kemudian berkembang yang didukung oleh disiplin ilmu yang lainnya. Untuk riset akuntansi keperilakuan yang pertama kali berkembang adalah akuntansi manajemen yang dikaitkan dengan isu budgeting (Sulastri, 2010). Kemudian terus berkembang dan bergeser ke arah akuntansi keuangan, sistem informasi akuntansi, dan audit. (Ardiansyah, 2009). Akuntansi keperilakuan yang berkaitan dengan anggaran dalam suatu perusahaan akan berdampak pada tingkat kinerja manajer perusahaan tersebut. Hal ini juga dipengaruhi oleh etika masing-masing individu tersebut.

Adapun tujuan penelitian ini adalah untuk menyajikan perkembangan riset akuntansi keperilakuan yang berhubungan dengan etika individu yang mengelola informasi. Hasil penelitian ini secara teoritis diharapkan dapat menjadi acuan bagi peneliti selanjutnya, khususnya dalam menemukan rujukan untuk menggali sumber pemikiran yang terkait dengan topik tentang akuntansi keperilakuan.

\section{TINJAUAN LITERATUR DAN FOKUS PENELITIAN \\ Etika}

Menurut Brooks (2012), dari segi etimologi (ilmu asal usul kata), etika berasal dari bahasa Yunani, ethos yang berarti watak kesusilaan atau adat. Dalam kamus umum bahasa Indonesia, etika diartikan ilmu pengetahuan tentang azaz-azaz akhlak (moral). Dari 
pengertian kebahasaan ini terlihat bahwa etika berhubungan dengan upaya menentukan tingkah laku manusia. Adapun arti etika dari segi istilah, telah dikemukakan para ahli dengan ungkapan yang berbeda-beda sesuai dengan sudut pandangnya.

\section{Macam Etika}

Ada dua macam etika yang harus kita pahami bersama dalam menentukan baik dan buruknya prilaku manusia:

1. Etika deskriptif, yaitu etika yang berusaha meneropong secara kritis dan rasional sikap dan prilaku manusia dan apa yang dikejar oleh manusia dalam hidup ini sebagai sesuatu yang bernilai. Etika deskriptif memberikan fakta sebagai dasar untuk mengambil keputusan tentang prilaku atau sikap yang mau diambil.

2. Etika normatif, yaitu etika yang berusaha menetapkan berbagai sikap dan pola perilaku ideal yang seharusnya dimiliki oleh manusia dalam hidup ini sebagai sesuatu yang bernilai. Etika normatif memberi penilaian sekaligus memberi norma sebagai dasar dan kerangka tindakan yang akan diputuskan.

\section{Etika Secara Umum dapat Dibagi Menjadi:}

Etika umum, berbicara mengenai kondisi-kondisi dasar bagaimana manusia bertindak secara etis, bagaimana manusia mengambil keputusan etis, teori-teori etika dan prinsip-prinsip moral dasar yang menjadi pegangan bagi manusia dalam bertindak serta tolak ukur dalam menilai baik atau buruknya suatu tindakan.
Etika umum dapat di analogkan dengan ilmu pengetahuan, yang membahas mengenai pengertian umum dan teoriteori.

Etika khusus merupakan penerapan prinsip-prinsip moral dasar dalam bidang kehidupan yang khusus. Penerapan ini bisa berwujud: bagaimana saya mengambil keputusan dan bertindak dalam bidang kehidupan dan kegiatan khusus yang saya lakukan, yang didasari oleh cara, teori dan prinsip-prinsip moral dasar. Namun, penerapan itu dapat juga berwujud: bagaimana saya menilai perilaku saya dan orang lain dalam bidang kegiatan dan kehidupan khusus yang dilatarbelakangi oleh kondisi yang memungkinkan manusia bertindak etis: bagaimana cara manusia mengambil suatu keputusan atau tindakan, dan teori serta prinsip moral dasar yang ada dibaliknya.

\section{Etika khusus dibagi lagi menjadi dua bagian:}

1. Etika individual, yaitu menyangkut kewajiban dan sikap manusia terhadap dirinya sendiri.

2. Etika sosial, yaitu berbicara mengenai kewajiban, sikap dan pola perilaku manusia sebagai anggota umat manusia.

Perlu diperhatikan bahwa etika individual dan etika sosial tidak dapat dipisahkan satu sama lain dengan jelas, karena kewajiban manusia terhadap diri sendiri dan sebagai anggota umat manusia saling berkaitan. Etika sosial menyangkut hubungan manusia dengan manusia baik secara langsung maupun secara kelembagaan (keluarga, masyarakat, negara), sikap kritis 
terhadap pandangan-pandangan dunia dan idiologi-idiologi maupun tanggung jawab umat manusia terhadap lingkungan hidup.

\section{Sistem Penilaian Etika}

Titik berat penilaian etika sebagai suatu ilmu adalah pada perbuatan baik atau jahat, susila atau tidak susila. Perbuatan atau kelakuan seseorang yang telah menjadi sifat baginya atau telah mendarah daging, itulah yang disebut akhlak atau budi pekerti. Budi tumbuhnya dalam jiwa, bila telah dilahirkan dalam bentuk perbuatan namanya pekerti. Jadi suatu budi pekerti, pangkal penilaiannya adalah dari dalam jiwa, dari semasih berupa angan-angan, cita-cita, niat hati, sampai ia lahir keluar berupa perbuatan nyata.

Kalangan ahli filsafat menjelaskan bahwa sesuatu perbuatan di nilai pada 3 (tiga) tingkat:

1. Tingkat pertama, semasih belum lahir menjadi perbuatan, jadi masih berupa rencana dalam hati, niat.

2. Tingkat kedua, setelah lahir menjadi perbuatan nyata, yaitu pekerti.

3. Tingkat ketiga, akibat atau hasil perbuatan tersebut, yaitu baik atau buruk.

Kata hati atau niat biasa juga disebut karsa atau kehendak, kemauan. Isi dari karsa inilah yang akan direalisasikan oleh perbuatan. Dalam hal merealisasikan ini ada (4 empat) variabel yang terjadi:

1. Tujuan baik, tetapi cara untuk mencapainya yang tidak baik.

2. Tujuannya yang tidak baik, cara mencapainya kelihatannya baik.
3. Tujuannya tidak baik, dan cara mencapainya juga tidak baik.

4. Tujuannya baik, dan cara mencapainya juga terlihat baik.

\section{Faktor yang Mempengaruhi Pelanggaran Etika}

Faktor - faktor yang dapat mempengarugi pelanggaran etika adalah sebagai berikut:

1. Kebutuhan individu seperti korupsi alasan ekonomi.

2. Tidak ada pedoman, area "abuabu", sehingga tak ada panduan.

3. Perilaku dan kebiasaan individu, seperti kebiasaan yang terakumulasi tak dikoreksi

4. Lingkungan tidak etis yang dipengaruhi dari komunitas

5. Perilaku orang yang ditiru, efek primordialisme yang kebablasan

\section{Sanksi Pelanggaran Etika}

Sanksi yang diterima karena melakukan pelanggaran etika adalah sebagai berikut:

1. Sanksi Sosial

Skala relative kecil, dipahami sebagai kesalahan yang dapat "dimaafkan".

\section{Sanksi Hukum}

Skala besar, merugikan hak pihak lain. Hukum pidana menempati prioritas utama, diikuti oleh hukum Perdata.

\section{Moral}

Adapun arti moral dari segi bahasa berasal dari bahasa latin, mores yaitu jamak dari kata mos yang berarti adapt kebiasaan. Di dalam kamus umum bahasa Indonesia dikatakan bahwa moral adalah penentuan baik buruk terhadap perbuatan dan kelakuan. Selanjutnya moral dalam arti istilah 
adalah suatu istilah yang digunakan untuk menentukan batas-batas dari sifat, perangai, kehendak, pendapat atau perbuatan yang secara layak dapat dikatakan benar, salah, baik atau buruk.

Berdasarkan kutipan tersebut diatas, dapat dipahami bahwa moral adalah istilah yang digunakan untuk memberikan batasan terhadap aktivitas manusia dengan nilai (ketentuan) baik atau buruk, benar atau salah. Jika pengertian etika dan moral tersebut dihubungkan satu dengan lainnya, kita dapat mengatakan bahwa antara etika dan moral memiki objek yang sama, yaitu sama-sama membahas tentang perbuatan manusia selanjutnya ditentukan posisinya apakah baik atau buruk. Namun demikian dalam beberapa hal antara etika dan moral memiliki perbedaan. Kalau dalam pembicaraan etika, untuk menentukan nilai perbuatan manusia baik atau buruk menggunakan tolak ukur akal pikiran atau rasio, sedangkan moral tolak ukurnya yang digunakan adalah normanorma yang tumbuh dan berkembang dan berlangsung di masyarakat. Dengan demikian etika lebih bersifat pemikiran filosofis dan berada dalam konsepkonsep, sedangkan moral berada dalam dataran realitas dan muncul dalam tingkah laku yang berkembang di masyarakat. Dengan demikian tolak ukur yang digunakan dalam moral untuk mengukur tingkah laku manusia adalah adat istiadat, kebiasaan dan lainnya yang berlaku di masyarakat.

Etika dan moral sama artinya tetapi dalam pemakaian sehari-hari ada sedikit perbedaan. Moral atau moralitas dipakai untuk perbuatan yang sedang dinilai, sedangkan etika dipakai untuk pengkajian sistem nilai yang ada. Kesadaran moral serta pola hubungannya dengan hati nurani yang dalam bahasa asing disebut conscience, conscientia, gewissen, geweten, dan bahasa arab disebut dengan qalb, fu'ad.

Dalam kesadaran moral mencakup tiga hal. Pertama, perasaan wajib atau keharusan untuk melakukan tindakan yang bermoral. Kedua, kesadaran moral dapat juga berwujud rasional dan objektif, yaitu suatu perbuatan yang secara umum dapat diterima oleh masyarakat, sebagai hal yang objektif dan dapat diberlakukan secara universal, artinya dapat disetujui berlaku pada setiap waktu dan tempat bagi setiap orang yang berada dalam situasi yang sejenis. Ketiga, kesadaran moral dapat pula muncul dalam bentuk kebebasan.

Berdasarkan pada uraian diatas, dapat disimpulkan bahwa moral lebih mengacu kepada suatu nilai atau sistem hidup yang dilaksanakan atau diberlakukan oleh masyarakat. Nilai atau sistem hidup tersebut diyakini oleh masyarakat sebagai yang akan memberikan harapan munculnya kebahagiaan dan ketentraman. Nilainilai tersebut ada yang berkaitan dengan perasaan wajib, rasional, berlaku umum dan kebebasan. Jika nilai-nilai tersebut telah mendarah daging dalam diri seseorang, maka akan membentuk kesadaran moralnya sendiri. Orang yang demikian akan dengan mudah dapat melakukan suatu perbuatan tanpa harus ada dorongan atau paksaan dari luar.

\section{Akhlak}


Pengertian Akhlak

Menurut Hasan dalam Wibowo (2012), akhlak berasal dari bahasa Arab "khuluqun" yang berarti perangai, tabiat, adat atau "khalqun" yang berarti kejadian, buatan, ciptaan. Jadi secara etimologi akhlak itu berarti perangai, adat, tabiat atau sistem perilaku yang dibuat. Secara sosiologis di Indonesia kata akhlak sudah mengandung konotasi baik, jadi orang yang berakhlak berarti orang yang berbudi baik. Pendapat lain mengenai akhlak menurut sebagian ulama yang disampaikan oleh Bakry dalam Wibowo (2012), menyatakan bahwa akhlak adalah suatu sifat yang terpendam dalam jiwa seseorang dan sifat itu akan timbul waktu ia bertindak tanpa ia merasa sulit (timbul dengan mudah). Secara umum akhlak Islam dibagi menjadi dua, yaitu akhlak mulia dan akhlak tercela. Akhlak mulia harus diterapkan dalam kehidupan sehari-hari, sedangkan akhlak tercela harus dijauhi jangan sampai dipraktikkan dalam kehidupan sehari-hari.

Adapun pembagian akhlak tersebut adalah sebagai berikut:

1. Akhlak yang Baik

Akhlak yang baik dan buruk dapat dilihat atau dapat tercermin dari perbuatan seseorang. Orang yang akhlaknya baik adalah orang yang besifat lapang dada, peramah dan pandai bergaul, tidak menyakiti hati orang lain, benar, tidak berdusta, sabar, dapat

dipercaya, baik dengan tetangga, katakata dan perbuatannya disenangi orang lain dan lain-lain sifat utama (Bakry dalam Wibowo, 2012). Dalam Islam disebutkan bahwa yang dimaksud dengan Akhlak yang baik ialah pola perilaku yang dilandaskan dan dimanifestasikan dari nilai-nilai Iman, Islam dan Ihsan. Adapun contoh-contoh akhlak yang baik menurut Hasan dalam Wibowo (2012) adalah sebagai berikut:

a. Akhlak yang berhubungan dengan Allah, meliputi: mentauhidkan Allah, takwa, berdoa, dzikrulloh dan tawakal.

b. Akhlak diri sendiri, meliputi: sabar, syukur, tawadhu (rendah hati, tidak sombong), benar, iffah (menahan diri dari melakukan yang terlarang), amanah/jujur dan merasa cukup dengan apa yang ada.

c. Akhlak terhadap keluarga, meliputi: birrul walidain (berbuat baik kepada orang tua), adil terhadap saudara, membina dan mendidik keluarga, dan memelihara keturunan

d. Akhlak terhadap masyarakat, meliputi: ukhuwah (persaudaraan), taawun (tolong menolong), adil, pemurah, penyantun, pemaaf, menepati janji, musyawarah dan saling wasiat dalam kebenaran.

e. Akhlak terhadap alam, meliputi: memperhatikan dan merenungkan penciptaan alam dan memanfaatkan alam.

Adapun diantara keutamaan akhlak yang baik menurut Mustofa dalam Wibowo (2012) adalah sebagai berikut:

a. Dimasukkan oleh Allah kedalam surga.

b. Pada hari kiamat didekatkan dengan Nabi Muhammad.

c. Hati merasa tenang.

d. Disukai banyak orang.

2. Akhlak yang Buruk 
Menurut Bakry dalam Wibowo (2012), akhlak yang buruk adalah akhlak yang tercermin dalam diri seseorang yang selalu bermuka masam, kasar tabiatnya, tidak sopan, sombong, pendusta, penakut, dan berbagai sifat yang tidak baik. Orang yang buruk akhlaknya menjadikan orang lain benci kepadanya, menjadi celaan dan tersisih dari pergaulan dan menyusahkan orang lain. Dalam bermasyarakat ia selalu resah, tidak

mempunyai teman, dan tidak disukai masyarakatnya. Adapun pangkal dari segala akhlak yang tercela adalah kesombongan, penghinaan dan peremehan.

Lima ciri yang terdapat dalam perbuatan akhlak, yaitu; pertama, perbuatan akhlak adalah perbuatan yang telah tertanam kuat dalam jiwa seseorang, sehingga telah

menjadi kepribadiaannya. Kedua, perbuatan akhlak adalah perbuatan yang dilakukan dengan mudah dan tanpa pemikiran. Ini tidak berarti bahwa saat melakukan sesuatu perbuatan, yang bersangkutan dalam keadaan tidak sadar, hilang ingatan, tidur atau gila. Ketiga, bahwa perbuatan akhlak adalah perbuatan yang timbul dari dalam diri orang yang mengerjakannya, tanpa ada paksaan atau tekanan dari luar. Perbuatan akhlak adalah perbuatan yang dilakukan atas dasar kemauan, pilihan dan keputusan yang bersangkutan. Keempat, bahwa perbuatan akhlak adalah perbuatan yang dilakukan dengan sesungguhnya, bukan mainmain atau karena bersandiwara. Kelima, sejalan dengan ciri yang keempat perbuatan akhlak (khususnya akhlak yang baik) adalah perbuatan yang dilakukan karena ikhlas semata-mata karena Allah, bukan karena ingin dipuji orang atau karena ingin mendapatkan suatu pujian.

\section{Profesi}

Menurut Agoes (2006), istilah profesi telah dimengerti oleh banyak orang bahwa suatu hal yang berkaitan dengan bidang yang sangat dipengaruhi oleh pendidikan dan keahlian. Tetapi dengan keahlian saja yang diperoleh dari pendidikan kejuruan, juga belum cukup disebut profesi. Tetapi perlu penguasaan teori sistematis yang mendasari praktik pelaksanaan, dan hubungan antara teori dan penerapan dalam praktik.

\section{Ciri-ciri Profesi}

Secara umum ada beberapa ciri atau sifat yang selalu melekat pada profesi, yaitu:

a. Adanya pengetahuan khusus, yang biasanya keahlian dan keterampilan ini dimiliki

berkat pendidikan, pelatihan dan pengalaman yang bertahun-tahun.

b. Adanya kaidah dan standar moral yang sangat tinggi. Hal ini biasanya setiap pelaku

profesi mendasarkan kegiatannya pada kode etik profesi.

c. Mengabdi pada kepentingan masyarakat, artinya setiap pelaksana profesi harus meletakkan kepentingan pribadi di bawah kepentingan masyarakat.

d. Ada izin khusus untuk menjalankan suatu profesi. Setiap profesi akan selalu berkaitan dengan kepentingan masyarakat, dimana nilai-nilai kemanusiaan berupa keselamatan, 
keamanan, kelangsungan hidup dan sebagainya, maka untuk menjalankan suatu profesi harus terlebih dahulu ada izin khusus.

e. Kaum profesional biasanya menjadi anggota dari suatu profesi.

Dengan melihat ciri-ciri umum profesi di atas, kita dapat menyimpulkan bahwa kaum profesional adalah orang-orang yang memiliki tolak ukur perilaku yang berada di atas ratarata. Di satu pihak ada tuntutan dan tantangan yang sangat berat, tetapi di lain pihak ada suatu kejelasan mengenai pola perilaku yang baik dalam rangka kepentingan masyarakat. Seandainya semua bidang kehidupan dan bidang kegiatan menerapkan suatu standar profesional yang tinggi, bisa diharapkan akan tercipta suatu kualitas masyarakat yang semakin baik.

\section{Prinsip-prinsip Etika Profesi}

1. Tanggung jawab

a. Terhadap pelaksanaan pekerjaan itu dan terhadap hasilnya.

b. Terhadap dampak dari profesi itu untuk kehidupan orang lain atau masyarakat pada

umumnya.

2. Keadilan

Prinsip ini menuntut kita untuk memberikan kepada siapa saja apa yang menjadi haknya.

3. Otonomi

Prinsip ini menuntut agar setiap kaum profesional memiliki dan di beri kebebasan dalam menjalankan profesinya.

\section{Peran Etika dalam Profesi}

Nilai-nilai etika itu tidak hanya milik satu atau dua orang, atau segolongan orang saja, tetapi milik setiap kelompok masyarakat, bahkan kelompok yang paling kecil yaitu keluarga sampai pada suatu bangsa. Dengan nilai-nilai etika tersebut, suatu kelompok diharapkan akan mempunyai tata nilai untuk mengatur kehidupan bersama. Salah satu golongan masyarakat yang mempunyai nilai-nilai yang menjadi landasan dalam pergaulan baik dengan kelompok atau masyarakat umumnya maupun dengan sesama anggotanya, yaitu masyarakat profesional. Golongan ini sering menjadi pusat perhatian karena adanya tata nilai yang mengatur dan tertuang secara tertulis (yaitu kode etik profesi) dan diharapkan menjadi pegangan para anggotanya.

Sorotan masyarakat menjadi semakin jelas manakala perilakuperilaku sebagian para anggota profesi yang tidak didasarkan pada nilai-nilai pergaulan yang telah disepakati bersama (tertuang dalam kode etik profesi), sehingga terjadi kemerosotan etik pada masyarakat profesi tersebut. Sebagai contohnya adalah pada profesi hukum dikenal adanya mafia peradilan, demikian juga pada profesi dokter dengan pendirian klinik super spesialis di daerah mewah, sehingga masyarakat miskin tidak mungkin menjamahnya.

Oleh karena itu dapatlah disimpulkan bahwa sebuah profesi hanya dapat memperoleh kepercayaan dari masyarakat, bilamana dalam diri para elit profesional tersebut ada kesadaran kuat untuk mengindahkan etika profesi pada saat mereka ingin memberikan jasa keahlian profesi kepada masyarakat yang memerlukannya. Tanpa etika profesi, 
apa yang semula dikenal sebagai sebuah profesi yang terhormat akan segera jatuh terdegradasi menjadi sebuah pekerjaan pencarian nafkah biasa (okupasi) yang sedikitpun tidak diwarnai dengan nilai-nilai idealisme dan ujung-ujungnya akan berakhir dengan tidak adanya lagi respek maupun kepercayaan yang pantas diberikan kepada para elite profesional ini.

Penerapan prinsip etika pofesi Ikatan Akuntan Indonesia (IAI) :

1. Tanggung jawab penerapan

Sebagai profesional, anggota mempunyai peran penting dalam masyarakat. Sejalan dengan peranan tersebut, anggota mempunyai tanggung jawab kepada semua pemakai jasa profesional mereka. Anggota juga harus selalu bertanggung jawab untuk bekerja sama dengan sesama anggota untuk mengembangkan profesi akuntansi, memelihara kepercayaan masyarakat, dan menjalankan tanggung-jawab profesi dalam mengatur dirinya sendiri. Usaha kolektif semua anggota diperlukan untuk memelihara dan meningkatkan tradisi profesi.

2. Kepentingan publik

Setiap anggota berkewajiban untuk senantiasa bertindak dalam kerangka pelayanan kepada publik, menghormati kepercayaan publik, dan menunjukkan komitmen atas profesionalisme.

3. Integritas

Integritas adalah suatu elemen karakter yang mendasari timbulnya pengakuan profesional. Integritas merupakan kualitas yang melandasi kepercayaan publik dan merupakan patokan (benchmark) bagi anggota dalam menguji semua keputusan yang diambilnya. Integritas mengharuskan seorang anggota untuk, antara lain, bersikap jujur dan berterus terang tanpa harus mengorbankan rahasia penerima jasa.

4. Obyektifitas

Obyektivitas adalah suatu kualitas yang memberikan nilai atas jasa yang diberikan anggota. Prinsip obyektivitas mengharuskan anggota bersikap adil, tidak memihak, jujur secara intelektual, tidak berprasangka atau bias, serta bebas dari benturan kepentingan atau berada di bawah pengaruh pihak lain.

5. Kehati-hatian

Kehati-hatian profesional mengharuskan anggota untuk memenuhi tanggung jawab profesionalnya dengan kompetensi dan ketekunan. Hal ini mengandung arti bahwa anggota mempunyai kewajiban untuk melaksanakan jasa profesional dengan sebaik-baiknya sesuai dengan kemampuannya, demi kepentingan pengguna jasa dan konsisten dengan tanggung-jawab profesi kepada publik.

6. Kerahasiaan

Setiap anggota harus menghormati kerahasiaan informasi yang diperoleh selama melakukan jasa profesional dan tidak boleh memakai atau mengungkapkan informasi tersebut tanpa persetujuan, kecuali bila ada hak atau kewajiban profesional atau hukum untuk mengungkapkannya.

7. Konsistensi

Konsistensi merupakan konsep dalam akuntansi yang menuntut diterapkannya standar secara terus- 
menerus, tidak di ubah-ubah kecuali dengan alasan yang dapat dibenarkan.

8. Standar teknis

Setiap anggota harus melaksanakan jasa profesionalnya sesuai dengan standar teknis dan standar proesional yang relevan. Sesuai dengan keahliannya dan dengan berhati-hati, anggota mempunyai kewajiban untuk melaksanakan penugasan dari penerima jasa selama penugasan tersebut sejalan dengan prinsip integritas dan obyektivitas. Standar teknis dan standar profesional yang harus ditaati anggota adalah standar yang dikeluarkan oleh lkatan Akuntan Indonesia, International Federation of Accountants, badan pengatur, dan peraturan perundangundangan yang relevan.

\section{Akuntansi Keperilakuan}

Ilmu Akuntansi keperilakuan memfokuskan pada hubungan antara perilaku manusia dan sistem akuntansi. Mereka menyadari bahwa proses akuntansi termasuk di dalamnya meringkas sejumlah kejadian ekonomi dimana hal-hal tersebut merupakan akibat dari perilaku manusia dan bahwa pengukuran akuntansi yang mereka lakukan termasuk di antara faktor-faktor yang mempengaruhi perilaku, yang menentukan sukses tidaknya kejadian ekonomi. Ilmu akuntansi keperilakuan melihat realita yang terjadi dalam suatu perusahaan yang berkaitan dengan perilaku karyawan perusahaan tersebut. Akuntansi keperilakuan sama seperti ilmu disiplin induknya (akuntansi). Ilmu ini merupakan terapan dan praktik. Ilmu ini menggunakan hasil penelitian disiplin ilmu induknya (ilmu keperilakuan) untuk menjelaskan dan memprediksi perilaku manusia.

Ikhsan (2005) dalam Putri (2008) menyatakan bahwa tujuan ilmu keperilakuan adalah untuk memahami, menjelaskan, dan memprediksi perilaku manusia sampai pada generalisasi yang ditetapkan mengenai perilaku manusia yang didukung oleh empiris yang dikumpulkan secara impersonal melalui prosedur yang terbuka, baik untuk peninjauan maupun replikasi dan dapat diverifikasi oleh ilmuwan lainnya yang tertarik.

Akuntansi keperilakuan menyediakan suatu kerangka yang disusun berdasarkan teknik yang bertujuan untuk memahami dan mengukur dampak proses bisnis terhadap orang-orang dan kinerja perusahaan, untuk mengukur dan melaporkan perilaku serta pendapat yang relevan terhadap perencanaan strategis dan untuk mempengaruhi pendapat dan perilaku guna memastikan keberhasilan implementasi kebijakan usaha. Akuntansi keperilakuan memperhatikan hubungan antara perilaku manusia dan akuntansi. Akuntansi keperilakuan juga berkepentingan pada bagaimana pengaruh tersebut dapat dirubah oleh perubahan era atau gaya yang dibawa dan bagaimana laporan akuntansi dan prosedur dapat digunakan paling efektif untuk membantu individu dan organisasi mencapai tujuan mereka.

\section{METODE PENELITIAN}

\section{Teknik Analisis Data}

Dalam penelitian ini, penulis memadukan hasil dari beberapa riset 
yang telah dilakukan sebelumnya yang berkaitan dengan akuntansi keperilakuan. Penelitian ini menggunakan metode literature research.

\section{HASIL DAN PEMBAHASAN}

Menurut Kachelmeir (2010), masalah yang ada dalam riset akuntansi memiliki dua keterkaitan yaitu kemandirian peneliti yang berbeda dalam menilai akuntansi keperilakuan dan pengaruh dari perilaku individu yang berbeda. Sehingga manajer fokus pada beberapa bagian dalam penganggaran manajemen laba (Bamber, 2010). Memang dalam praktiknya, banyak cara yang dilakukan manajer untuk mempermainkan besar kecilnya laba menurut Sulistyanto (2008). Seperti mengakui dan mencatat pendapatan terlalu cepat atau sebaliknya, mengakui dan mencatat pendapatan palsu, mengakui dan mencatat biaya lebih cepat atau lebih lambat dari yang seharusnya, dan tidak mengungkapkan kewajibannya. Upayaupaya seperti ini sulit untuk diketahui oleh pemakai laporan keuangan karena kurang lengkapnya pengungkapan suatu laporan keuangan. Hal ini bisa tidak terjadi dimana dalam pelaksanaannya menerapkan prinsip etika profesi yaitu tanggung jawab, obyektifitas, dan mematuhi standar teknis yang telah ditetapkan. Selain itu, akhlak dari masing-masing individu yang dimiliki akan mendukung dalam penerapan etika profesi tersebut.

Hasil riset Murni dan Andriana (2007) menunjukkan kepemilikan institusional memiliki wewenang lebih besar dibandingkan dengan pemegang saham kelompok lain sehingga cenderung memilih proyek yang lebih berisiko dengan harapan akan memperoleh keuntungan yang tinggi. Kepemilikan manajerial menunjukkan adanya peran ganda seorang manajer, yakni manajer juga bertindak sebagai pemegang saham. Sebagai seorang manajer sekaligus pemegang saham, ia tidak ingin perusahaan mengalami kesulitan keuangan atau bahkan kebangkrutan. Kesulitan keuangan atau kebangkrutan usaha akan merugikan ia baik sebagai manajer atau sebagai pemegang saham. Sebagai manajer akan kehilangan insentif dan sebagai pemegang saham akan kehilangan return bahkan dana yang diinvestasikannya. Cara untuk menurunkan resiko ini adalah dengan menurunkan tingkat debt yang dimiliki perusahaan (Friend and Lang dalam Christiawan dan Josua, 2007). Debt yang tinggi akan meningkatkan resiko kebangkrutan perusahaan, karena perusahan akan mengalami financial distress. Karena itulah maka manajer akan berusaha menekan jumlah debt serendah mungkin. Tindakan ini di sisi lain tidak menguntungkan karena perusahaan hanya mengandalkan dana dari pemegang saham. Perusahaan tidak bisa berkembang dengan cepat, dibandingkan jika perusahaan juga menggunakan dana dari kreditor. Kondisi tersebut membutuhkan keputusan yang tepat demi kelangsungan perusahaan. Oleh karena itu diperlukan etika profesi yang benar serta akhlak individu yang baik untuk mendukung proses pengambilan keputusan yang tepat. 
Kemudian, Faccio (2006) menemukan dorongan perusahaan untuk memiliki koneksi politik telah mendapat perhatian khusus dari para pengamat ekonomi karena adanya indikasi perlakuan istimewa dari pemerintah, terlebih bagi perusahaan yang dimiliki langsung oleh pejabat atau orang yang memegang posisi penting di dalam pemerintahan. Perusahaan dikatakan memiliki koneksi politik apabila minimal salah satu pemegang saham utama (orang yang memiliki paling tidak 10 persen dari total hak suara) atau salah satu pimpinan (CEO, presiden, wakil presiden, ketua atau sekretaris) merupakan anggota parlemen, menteri atau memiliki relasi dengan politikus atau partai politik. Riset Butje dan Tjondro (2014) menunjukkan perusahaan tidak selalu menggunakan koneksi politik untuk melakukan tax avoidance tetapi bisa digunakan untuk mendapatkan bantuan modal dan berbagai keuntungan dari sisi pendanaan. Hal ini berarti masih ada beberapa individu yang memperhatikan etika profesi dalam pelaksanaanya dan juga memiliki akhlak yang baik sehingga dalam penelitian Butje dan Tjondro (2014) tersebut menunjukkan tidak selalu individu menggunakan koneksi politik untuk melakukan tax avoidance.

Eksekutif memegang peranan penting dalam menentukan skema penghindaran pajak perusahaan diperkuat oleh penelitian yang dilakukan oleh Dyreng et al. (2008) dan Budiman (2012). Peranan eksekutif tidak hanya mampu menambah nilai perusahaan tetapi juga memiliki kecenderungan untuk mendukung penghindaran pajak. Salah satu cara yang dilakukan eksekutif adalah dengan menempatkan orang kepercayaan yang memiliki keahlian untuk mengamati sekaligus membuat skema penghindaran pajak sesuai keinginan eksekutif (Dyreng et al.,2009). Budiman (2012) menyatakan semakin eksekutif bersifat risk taker akan semakin tinggi tingkat penghindaran pajak yang dilakukan perusahaan. Butje dan Tjondro (2014) menemukan semakin eksekutif bersifat risk taker, semakin tinggi tax avoidance yang dilakukan perusahaan. Eksekutif risk taker seperti ini harusnya memiliki akhlak yang baik yang tercermin dalam penerapan etikan profesi ketika menjalankan usahanya, seperti pembuatan tax planning, namun bila tidak maka akan memperoleh sanksi karena melanggar etika profesi tersebut.

Adakalanya partisipasi dalam penyusunan anggaran dapat menimbulkan permasalahan baru. Schiff dan Lewin dalam Arifin (2007) menganggap bahwa adanya kelonggaran dalam anggaran (slack) merupakan hasil dari proses partisipasi, dan mereka yakin bahwa para manajer memperjuangkan secara sengaja sehingga mereka dapat mencapai tujuan pribadi seperti gaji yang lebih tinggi, bonus, dan lain-lain. Semua hal tersebut dapat terwujud jika anggaran dapat dicapai. Keikutsertaan para manajer dalam penyusunan anggaran akan berakibat mereka (para manajer) menetapkan ang-garan yang relatif mudah (longgar), sehingga akan menimbulkan slack yang mengecilkan prestasi yang diharapkan (Chow dalam 
Arifin, 2007). Hal ini terjadi karena mereka mengetahui bahwa prestasi mereka akan dinilai dari anggaran tersebut. Banyak cara yang digunakan untuk mencapai suatu kesejahteraan namun cara tersebut melanggar etika profesi yang ada dan mencerminkan akhlak yang buruk. Bukan hal yang bagus ketika mendapatkan suatu pengakuan hasil kinerja yang bagus namun dalam prosesnya melanggar etika dan profesi dan memperburuk moral dan akhlak yang dimiliki. Pengakuan hasil kinerja tersebut juga tidak akan bertahan lama, karena akan masih banyak lagi tantangan-tantangan dalam pekerjaan yang dihadapi dimana itu akan melibatkan etika profesi, moral dan akhlak yang dimiliki dalam penentuan hasilnya.

\section{PENUTUP}

Berdasarkan analisis literature research tersebut dapat disimpulkan bahwa setiap individu dalam pelaksaan tugas profesinya harus memperhatikan etika-etika profesi, moral dan akhlak dalam pelaksanaan suatu profesi seperti dalam pemanfaatan wewenang kepemilikan, menjalin koneksi dengan politikus, membangun karakter manajer, dan dalam penyusunan anggaran perusahaan. Moral, akhlak dan etika profesi sangat penting diterapkan guna mendukung kelancaran dalam operasional perusahaan baik dari sisi kebijakan ataupun lainnya di masa sekarang maupun masa yang akan datang.

Implikasi dalam penelitian ini bisa menjadi panduan dalam pelaksanaan akuntansi keperilakuan dimana harus tetap memperhatikan etika profesi. Karena etika profesi memegang peranan penting dalam proses pelaksanaan akuntansi keperilakuan. Selain itu, moral dan akhlak yang dimiliki masing-masing individu juga sangat berperan penting sehingga moral dan akhlak yang dimiliki itu adalah moral dan akhlak yang baik.

Keterbatasan dalam penelitian ini adalah masih kurangnya hasil-hasil riset yang bisa mendukung penelitian ini. Hal ini karena keterbatasan waktu peneliti.

Oleh karena itu, saran dari penelitian ini perlu dilakukan lagi penelitian seperti ini dengan lebih banyak melibatkan riset-riset lain yang dapat meningkatkan ilmu pengetahuan tentang akuntansi keperilakuan dan perlunya waktu yang cukup.

\section{DAFTAR PUSTAKA}

Agoes, Sukrisno. 2006. Etika Bisnis dan Profesi: tantangan membangun manusia seutuhnya. Yogyakarta: AMP YKPN. 
Ardiansyah, Misnen. 2009. Perkembangan Penelitian Akuntansi Keperilakuan. SosioReligia, Vol. 8, No. 3.749 - 771.

Arifin, Johan. 2007. Pengaruh Karakteristik Gaya Penyusunan Anggaran Terhadap Efisiensi Biaya. Sinergi Kajian Bisnis dan Manajemen. Vol. 9. No. 1. 23-35.

Bamber, L. S., J. X. Jiang, and I. Y. Wang. 2010. What's my style? The influence of top managers on voluntary corporate financial disclosure. The Accounting Review 85 _July_: 1131-1162.

Brooks, Leonard J. dan Paul Dunn. 2012. Business and Professional Ethics for Directors, Executives and Accountants. Edisi 6. Mason City: South - Western Cengage Learning. Diakses dari books.google.co.id pada tanggal 25 Desember 2015.

Budiman, J. 2012. Pengaruh Karakter Eksekutif Terhadap Penghindaran Pajak (Tax Avoidance) .Doctoral Dissertation. Universitas Gadjah Mada).

Butje, Stella dan Elisa Tjondro. 2014. Pengaruh Karakter Eksekutif dan Koneksi Politik Terhadap Tax Avoidance. Tax and Accounting Review. Vol 4. No. 2. 1-9.

Christiawan, Yulius Jogi, dan Josua Tarigan. 2007. Kepemilikan Managerial: Kebijakan Hutang, Kinerja dan Nilai Perusahaan. Jurnal Akuntansi dan Keuangan. Vol. 9. No. 1. 1-8.

Dyreng, S. D., Hanlon, M., \& Maydew, E. L. 2008. Long-Run Corporate Tax Avoidance. The Accounting Review. 83(1). 61-82.

Faccio, M. 2006. Politically Connected Firms. The American Economic Review, 369386.

Ikatan Akuntan Indonesia. 2012. Standar Akuntansi Keuangan. PSAK. Cetakan keempat. Buku Satu. Jakarta: Salemba Empat.

Kachelmeier, Steven J. 2010. Introduction to a Forum on Individual Differences in Accounting Behavior. The Accounting Review. Vol. 85. 1-2.

Murni, Sri dan Andriana. 2007. Pengaruh Insider Ownership, Institutional Investor, Dividend Payments, dan Firm Growth Terhadap Kebijakan Hutang Perusahaan (Studi Kasus pada Perusahaan Manufaktur yang Terdaftar di Bursa Efek Jakarta). Jurnal Akuntansi dan Bisnis. Vol. 7.No. 1. 15-24. 
Putri, I G. A.M, Asri, Dwija. 2008. Implikasi Riset Akuntansi Keperilakuan Terhadap Pengembangan Akuntansi Manajemen. Jurnal Ilmiah Akuntansi dan Bisnis. Vol. 3. No. 2. 1-17.

Sulistyanto, Sri. 2008. Manajemen Laba: Teori dan Model Empiris. Grasindo: Jakarta.

Sulastri. Putu. 2010. Akuntansi Keperilakuan Terhadap Pengembangan Akuntansi Manajemen . Dharma Ekonomi. Vol. 17. No. 32. 1-16.

Wibowo, Ari. 2012. Pembinaan Akhlak Melalui Metode Pembiasaan Bagi Siswa MTS. Negeri Pakem Sleman. Skripsi. digilib.uin-suka.ac.id/10158/ di akses 14 Mei 2016. 